\title{
Carbon Supported Size-Controlled Ru Catalysts for Selective Levulinic Acid Hydrogenation into $\gamma$-Valerolactone
}

\author{
Irina L. Simakova*a,b, Yuliya S. Demidova ${ }^{a, b}$, \\ Mikhail N. Simonov, ${ }^{a, b}$, Prashant S. Niphadkar ${ }^{c}$, \\ Vijay V. Bokade ${ }^{c}$, Nandini Devi ${ }^{c}$, \\ Paresh L. Dhepe ${ }^{c}$ and Dmitry Yu. Murzind \\ ${ }^{a}$ Boreskov Institute of Catalysis \\ Novosibirsk, Russian Federation \\ ${ }^{b}$ Novosibirsk State University \\ Novosibirsk, Russian Federation \\ ${ }^{c}$ CSIR-National Chemical Laboratory \\ Pune, India \\ 'Process Chemistry Centre, Abo Akademi University \\ Turku, Finland
} Received 28.06.2019, received in revised form 16.10.2019, accepted 29.12.2019

Abstract. Liquid phase levulinic acid hydrogenation into $\gamma$-valerolactone in 1,4-dioxane as a solvent $\left(165^{\circ} \mathrm{C}, 20 \mathrm{bar}\right)$ was studied over a range of $\mathrm{Ru}$ monometallic catalysts using mesoporous carbon material Sibunit as a support. In addition to the catalyst prepared by impregnation with $\mathrm{RuCl}_{3} \cdot \mathrm{nH}_{2} \mathrm{O}(0.1 \mathrm{M})$ followed by reduction in $\mathrm{H}_{2}$, size-controlled $\mathrm{Ru}(\mathrm{NPs}) /$ Sibunit catalysts were synthesized by immobilization of polyvinylpyrrolidone (PVP) stabilized Ru nanoparticles (NPs) $\left(\mathrm{d}_{\mathrm{Ru}}=2.4 \mathrm{~nm}\right)$. Carbon supported colloidal Ru NPs were not studied earlier in levulinic acid hydrogenation. Activity of colloidal Ru(NPs)/Sibunit catalysts was found to be lower than that of impregnated $\mathrm{Ru} /$ Sibunit which could be attributed to hampering effect of PVP. However, colloidal $\mathrm{Ru}(\mathrm{NPs}) /$ Sibunit purified by thermal treatment in air $\left(180^{\circ} \mathrm{C}\right)$ followed by reduction in $\mathrm{H}_{2}\left(400^{\circ} \mathrm{C}\right)$ exhibited the same activity as impregnated one yielding 93\% $\gamma$-valerolactone at $100 \%$ levulinic acid conversion. Applicability of supported PVP-assisted colloidal Ru NPs in hydrogenation of levulinic acid illustrates a potential to prepare more efficient catalysts for this reaction with a desired particle size. The catalysts were characterized by TEM, XRF, and $\mathrm{N}_{2}$ physisorption to compare their physical chemical properties.

(C) Siberian Federal University. All rights reserved

This work is licensed under a Creative Commons Attribution-NonCommercial 4.0 International License (CC BY-NC 4.0)

* Corresponding author E-mail address: simakova@catalysis.ru 
Keywords: levulinic acid, hydrogenation, gamma-valerolactone, $\mathrm{Ru}$ catalysts, $\mathrm{Ru}$ colloidal nanoparticles, effect of polyvinylpyrrolidone, size effect.

Citation: Simakova I.L., Demidova Yu.S., Simonov M.N., Niphadkar P.S., Bokade V.V., Devi N., Dhepe P.L., Murzin D.Yu. Carbon supported size-controlled Ru catalysts for selective levulinic acid hydrogenation into $\gamma$-valerolactone, J. Sib. Fed. Univ. Chem., 2020, 13(1), 5-16. DOI: 10.17516/1998-2836-0166

\title{
Рутениевые катализаторы на углеродном носителе \\ с контролируемым размером частиц \\ для селективного гидрирования левулиновой кислоты \\ в $\gamma$-валеролактон
}

\author{
И.Л. Симакова ${ }^{* a, \tilde{\sigma}}$ Ю.С. Демидова ${ }^{a, \tilde{\sigma}}$, \\ М.Н. Симонова ${ }^{a, \tilde{\sigma}}$, П.С. Нипхадкар ${ }^{\text {в }}$ В.В. Бокаде ${ }^{\text {, }}$ \\ Н. Деви \\ ${ }^{a}$ Институт катализа им. Г.К. Борескова СО РАН \\ Российская Федерачия, Новосибирск \\ ${ }^{\sigma}$ Новосибирский государственный университет \\ Российская Федерачия, Новосибирск \\ ${ }^{6}$ Начиональная химическая лаборатория \\ Индия, Пуна \\ Кафедра промьиленнойхимии \\ и инженерии химических реакций, Академия Або \\ Финляндия, Турку
}

Аннотациия. Жидкофазное гидрирование левулиновой кислоты (ЛК) в $\gamma$-валеролактон (ГВЛ) было изучено в присутствии Ru на мезопористом углеродном носителе Сибунит (растворитель 1,4-диоксан, $165^{\circ} \mathrm{C}$, давление водорода 20 бар). Наряду с катализаторами, приготовленными методом пропитки раствором $\mathrm{RuCl}_{3} \mathrm{nH}_{2} \mathrm{O}(0,1 \mathrm{M})$ с последующим восстановлением в $\mathrm{H}_{2}$, были синтезированы катализаторы Ru/Сибунит с контролируемым размером частиц $\mathrm{Ru}$ путем иммобилизации стабилизированных поливинилпирролидоном (ПВП) наночастиц (НЧ) $\mathrm{Ru}$ $\left(\mathrm{d}_{\mathrm{Ru}} 2,4\right.$ нм), ранее не исследованные в гидрировании ЛК. Показано, что активность коллоидных

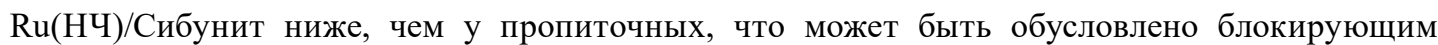
эффектом ПВП. Обработка на воздухе $\left(180^{\circ} \mathrm{C}\right)$ с последующим восстановлением в водороде

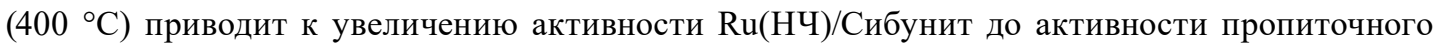
$\mathrm{Ru} /$ Сибунит с селективностью 93 \% по ГВЛ при 100\%-й конверсии ЛК. Эффективность ПВПстабилизированных коллоидных НЧ Ru в гидрировании ЛК открывает возможность получения более эффективных катализаторов для этой реакции с контролируемым размером частиц. Катализаторы изучены методами ПЭМ, РФлА и адсорбции азота. 
Ключевые слова: левулиновая кислота, гидрирование, $\boldsymbol{\gamma}$-валеролактон, $\mathrm{Ru}$ катализаторы, $\mathrm{Ru}$ коллоидные наночастицы, влияние поливинилпирролидона, размерный эффект.

Цитирование: Симакова, И.Л. Рутениевые катализаторы на углеродном носителе с контролируемым размером частиц для селективного гидрирования левулиновой кислоты в $\gamma$-валеролактон / И.Л. Симакова, Ю.С. Демидова, М.Н. Симонов, П.С. Нипхадкар, В.В. Бокаде, Н.Л. Деви, П. Дхепе, Д.Ю. Мурзин // Журн. Сиб. федер. ун-та. Химия, 2020. 13(1). C. 5-16. DOI: 10.17516/1998-2836-0166

\section{Introduction}

Recently a significant development has been made in the realm of colloidal catalysts [1]. Supported noble-metal nanoparticles (NPs) are considered among the industrially most relevant catalysts. They are applied in oil refinery, as exhaust gas catalysts, for bulk and fine chemicals production, and in electrocatalysis [2]. Due to high costs of noble metals, even minor improvements in performance can lead to significant ecological and economical benefits. Recent advances in the synthesis of colloidal metal nanoparticles with controlled sizes and shapes open a promising way for catalyst design [3]. GVL attracted considerable attention in the last years as a versatile building block. It can be used as a fuel additive, a solvent for biomass processing, as well as a precursor for production of hydrocarbons, polymers and other valuable chemicals, having thus a large potential to reduce consumption of petroleum-derived fossil fuels $[4,5]$.

Many heterogeneous $\mathrm{Ru} / \mathrm{C}$ were reported to be active in transformations of LA into GVL in different solvents, such as water [6], alcohols [7, 8], dioxane [9], and supercritical $\mathrm{CO}_{2}$ [10]. Carbon supported Ru catalysts showed high activity in formation of GVL from LA into GVL which can be related to the influence of the metal per se along with specific textural properties. Recently it was shown that a highly dispersed 5\% Ru on activated carbon catalyst prepared by a solvent-free microwaveassisted thermolytic method exhibited a superior catalytic performance compared with a less dispersed $\mathrm{Ru}$ supported on carbon and metal oxide supports. In the presence of this $5 \% \mathrm{Ru}$ /activated carbon catalyst GVL was produced with a high yield and $99 \%$ selectivity under mild reaction conditions $\left(100^{\circ} \mathrm{C}, 2.0 \mathrm{MPa}\right.$, LA aqueous solution $\left.0.10 \mathrm{~g} / \mathrm{mL}\right)$ [11]. Synthesis of metal nanoparticles (NPs) in the presence of a surfactant provides a precise control of the particle size, composition, shape and microstructure and demonstrates a great potential for catalytic applications. Synthesis and application of Ru colloidal catalysts was reported recently [12]. In our earlier works a colloidal method synthesis for Ru NPs immobilized on the carbon support was successfully developed [13]. It was shown that a highly concentrated colloidal solution of well-defined Ru NPs $(0.1 \mathrm{M})$ can be obtained by the polyol method using polyvinylpyrrolidone (PVP) as a stabilizing agent under a minor PVP excess (mol Ru/mol PVP monomer 1/5) [13]. High activity of colloidal catalysts was demonstrated in hydrogenation of galactose and arabinose into corresponding commercially valuable sugar alcohols [14, 15].

To the best of our knowledge colloidal Ru/carbon catalysts were not applied in the LA hydrogenation being able, however, to provide more efficient catalysts with well-defined metal particle sizes.

The current investigation is aimed at performing a comparative study of levulinic acid hydrogenation into $\gamma$-valerolactone under comparable reaction conditions using Ru catalysts supported on mesoporous carbon Sibunit prepared by two different ways: (i) immobilization of ready-made colloidal metallic Ru NPs, (ii) impregnation of the carbon support with $\mathrm{RuCl}_{3}$ followed by reduction with molecular hydrogen into metallic Ru NPs. 


\section{Experimental}

\subsection{Materials}

All starting materials of the reagent grade, i.e. levulinic acid ( $\geq 99 \%$, Acros Organics), 1,4-dioxane (TU 6-09-659-73), nitrogen ( $\geq 99.95 \%$ ), hydrogen ( $\geq 99.95 \%$ ), argon ( $\geq 99.95 \%)$, ethylene glycol and PVP (monomer weight 29700) were used without any purification. Mesoporous carbon Sibunit ( $\mathrm{S}_{\mathrm{BET}} 350 \mathrm{~m}^{2} / \mathrm{g}$ ) was applied as a catalyst support. $\mathrm{RuCl}_{3}$ hydrate (TU 2625-066-00196533-2002 Krastscvetmet, Krasnoyarsk) was used as a catalyst precursor.

\subsection{Preparation of colloidal Ru NPS}

Colloidal Ru NPs $(0.1 \mathrm{M})$ were synthesized by the polyol method using $\mathrm{RuCl}_{3} \cdot \mathrm{nH}_{2} \mathrm{O}$ and ethylene glycol (EG) as a metal precursor and a reducing agent, respectively. Generally, $\mathrm{RuCl}_{3} \times \mathrm{nH}_{2} \mathrm{O}$ and PVP (mol Ru/mol monomers PVP 1/5) were dissolved in EG under stirring and heating up to $198^{\circ} \mathrm{C}$ for $1 \mathrm{~h}$ [13] under reflux conditions. Immobilization of Ru NPs on the support was carried out through incipient wetness impregnation using alcohol solutions of metal NPs. To prepare alcohol colloidal NPs solution, the required colloid amount in ethylene glycol was added to acetone under Ar atmosphere. The volume ratio between acetone and the colloid was varied (acetone/colloid 13 or 77) to adjust the amount of PVP in the initial colloid. The suspension was shaken at room temperature for at least $17 \mathrm{~h}$. Thereafter acetone was removed by decantation and ethanol was added to NPs.

\subsection{Preparation of catalysts}

$4 \% \mathrm{Ru} /$ Sibunit was prepared by incipient wetness impregnation with an aqueous solution of $\mathrm{RuCl}_{3}$ hydrate $(0.1 \mathrm{M})$ followed by drying at $110^{\circ} \mathrm{C}$ for $17 \mathrm{~h}$ and reduction by molecular hydrogen from room temperature up to $352^{\circ} \mathrm{C}$ with a ramp rate of $2 \mathrm{~K} / \mathrm{min}$. In addition, the samples were treated with hydrogen during $3 \mathrm{~h}$ at $420^{\circ} \mathrm{C}$ temperature to remove the excess of chloride. The ethanol solution of colloidal Ru NPs was used for the preparation of Ru(NPs)/Sibunit catalysts with the metal loading ca. 3-4 wt.\%. After impregnation the samples were dried in an oven at $120^{\circ} \mathrm{C}$ for $24 \mathrm{~h}$.

\subsection{PVP removal procedures}

In order to remove the PVP, the as-synthesized catalysts were subjected to both solvothermal and thermal treatment. The solvothermal treatment was carried out in a Parr 4561 autoclave in water or an aqueous solution of acetic acid $(0.02$ and $0.08 \mathrm{M})$ at $220^{\circ} \mathrm{C}$ under nitrogen pressure 25 bar for $4 \mathrm{~h}$. After solvothermal treatment some samples were additionally reduced in $\mathrm{H}_{2}$ at $250^{\circ} \mathrm{C}\left(1.5^{\circ} \mathrm{C} / \mathrm{min}\right)$ for $1 \mathrm{~h}$. In the case of the thermal treatment, which was done contrary to solvothermal treatment in the absence of any solvent, the catalysts were treated under different conditions, varying both the temperature regime and gas atmosphere. The following thermal treatment was applied to remove PVP: $(A)$ air $180^{\circ} \mathrm{C}$, $10^{\circ} \mathrm{C} / \mathrm{min}, 0.5 \mathrm{~h}$ followed by $\mathrm{H}_{2} 400^{\circ} \mathrm{C}, 10^{\circ} \mathrm{C} / \mathrm{min}, 1 \mathrm{~h} ;(B) \mathrm{H}_{2} 400^{\circ} \mathrm{C}, 10^{\circ} \mathrm{C} / \mathrm{min}, 0.5 \mathrm{~h} ;(C) \mathrm{N}_{2} 500^{\circ} \mathrm{C}$, $10^{\circ} \mathrm{C} / \mathrm{min}, 2 \mathrm{~h} ;(D)$ air $180^{\circ} \mathrm{C}, 10^{\circ} \mathrm{C} / \mathrm{min}, 0.5 \mathrm{~h}$ followed by $\mathrm{H}_{2} 250^{\circ} \mathrm{C}, 1.5^{\circ} \mathrm{C} / \mathrm{min}, 1 \mathrm{~h} ;(E) \mathrm{Ar} 500^{\circ} \mathrm{C}$, $10^{\circ} \mathrm{C} / \mathrm{min}, 2 \mathrm{~h} ;(F)$ air $180^{\circ} \mathrm{C}, 10^{\circ} \mathrm{C} / \mathrm{min}, 0.5 \mathrm{~h}$.

\subsection{Catalysts characterization}

As synthesized metal nanoparticles and immobilized on carbon supports were analyzed by transmission electron microscopy (TEM) to estimate Ru NPs size, X-ray fluorescent analysis (XRF) to 
control Ru content, and low-temperature $\mathrm{N}_{2}$ physisorption to determine the pore volume, surface area and the average pore size.

TEM photographs were taken with a Hitachi-9000 NAR apparatus. The samples for TEM were prepared by placing a drop of a colloidal PVP-Ru dispersion or the sample suspension in ethanol onto a perforated carbon coated copper grid, followed by naturally evaporating the solvent. The mean particle diameter and the standard deviation were calculated by counting at least 250 NPs from the enlarged microphotographs.

Semi-quantitative analysis of metal concentration was performed using wavelength dispersive X-ray fluorescence (WDXRF) spectrometry with the powder pellet method. Undiluted samples $(0.5 \mathrm{~g})$ were milled and put in the $29 \mathrm{~mm}$ diameter die. The intensities of the metal lines in the samples were measured in vacuum conditions on an ARL Advant'X spectrometer equipped with a rhodium anode X-Ray tube. Excitation conditions were as follows: tube voltage of $50 \mathrm{kV}$; current of $40 \mathrm{~mA}$; collimator with a divergence of $0.25^{\circ}$; LiF200 crystal was used as a monochromator; scintillation counter was used as a detector; counting time was $12 \mathrm{~s}$. The content of elements in the sample was estimated using a semi-quantitative method by means of a QuantAS program for standard-less analysis.

The textural properties were determined using BET method by physisorption of nitrogen at $77 \mathrm{~K}$ in a Micromeritics Model ASAP 2400 equipment. The specific surface area was calculated using BET method within the relative partial pressure range of $0.05-0.25$.

\subsection{Catalytic experiments}

The liquid phase LA $(6.87 \mathrm{mmol})$ hydrogenation in an aprotic solvent 1,4-dioxane $(15 \mathrm{~mL})$ was carried out in a stainless steel autoclave $(150 \mathrm{~mL})$ with efficient stirring at a constant hydrogen pressure. In a typical experiment hydrogenation was performed with the catalyst amount of $0.03-0.24 \mathrm{~g}$ at $165^{\circ} \mathrm{C}$ and $20 \mathrm{bar}$ in the absence of mass transfer limitations as was established previously. The impact of internal diffusion was determined through the estimation of the WeiszPrater criterion.

Aliquots were withdrawn from the reactor at appropriate time intervals and analyzed by gas chromatography (Chromos GC-1000 chromatograph) equipped with a flame ionization detector using BP20 capillary column $(60 \mathrm{~m} / 0.25 \mathrm{~mm} / 0.25 \mu \mathrm{m})$ at $323-473 \mathrm{~K}$ and a heating rate of $10 \mathrm{~K} / \mathrm{min}$. For analysis of the liquid phase, the temperature was increased from 323 till $523 \mathrm{~K}$ with temperature ramp $10 \mathrm{~K} / \mathrm{min}$. The temperature of the detector was the same as for the evaporator being $523 \mathrm{~K}$, the carrier gas was hydrogen with the flow rate $20 \mathrm{~cm}^{3} / \mathrm{min}$. Identification of the reaction components was carried out by chromatography/mass spectrometry with VG-7070 GC/MS using ZB-Wax capillary column (length $30 \mathrm{~m} /$ inner diameter $0.25 \mathrm{~mm} / \mathrm{film}$ thickness $0.25 \mu \mathrm{m})$ and Agilent 5973N EI/PCI using VF-5ms capillary column $(30 \mathrm{~m} / 0.25 \mathrm{~mm} /$ $0.25 \mu \mathrm{m})$.

Conversion of LA and selectivity to GVL were estimated from the peak areas based on the internal standard technique using GC keeping $100 \%$ mass balance for carbon containing reaction components. Selectivity to GVL was calculated based on the following equation: selectivity yield of the product/ total yield of all products. 


\section{Results and discussion}

\subsection{Characterization of Ru/Sibunit and Ru(NPs)/Sibunit}

For $4 \% \mathrm{Ru} / \mathrm{Sibunit}$ prepared by incipient wetness impregnation with an aqueous solution of $\mathrm{RuCl}_{3}$ hydrate $(0.1 \mathrm{M})$ TEM analysis showed that Ru NPs have a spherical shape uniformly distributed on the carbon support surface bearing the mean NPs size of ca. $2.1 \mathrm{~nm}$ (Fig. 1).

Colloidal Ru NPs were synthesized by the polyol method in EG using PVP as a capping agent similar to the method presented in [13-16]. This method was shown to provide formation of highly concentrated solutions of colloidal Ru NPs with a relatively low amount of the capping agent (Ru/PVP 1/5) demonstrating good stability at least during 24 months. TEM data for as-synthesized Ru NPs are presented in Fig. 2. Ru NPs with an average particle size of $2.4 \mathrm{~nm}$ were immobilized on the surfaces of Sibunit. TEM analysis (Fig. 3) of Ru(NPs)/Sibunit showed that uniformly distributed on the carbon support surface Ru NPs have a spherical shape and mean NPs size of ca. $2.9 \mathrm{~nm}$ (Fig. 3).

\subsection{Comparison of Ru/Sibunit and Ru(NPs)/Sibunit catalyst activities}

According to GC analysis the main reaction product of LA hydrogenation is GVL. The minor products were pentanoic acid and 2-methyltetrahydrofurane with the overall content not exceeding $5 \%$. Generally, GVL can be synthesized by hydrogenation of LA using one of the reaction mechanisms (Fig. 4): first step - hydrogenation of the ketone group of LA, leading to the formation of an unstable intermediate 4-hydroxypentanoic acid, and second step - subsequent dehydration followed by an intramolecular esterification resulting in the ring formation of GVL [17].

a)

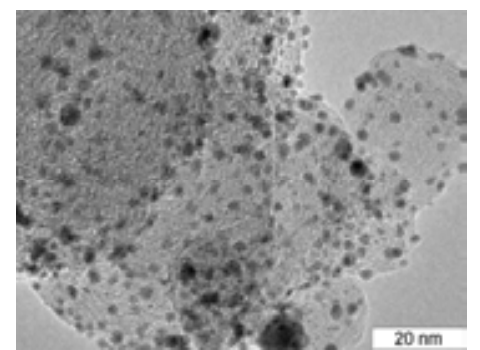

b)

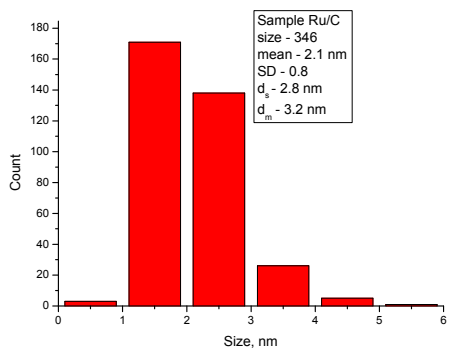

Fig. 1. TEM images (a) and histograms (b) of Ru/Sibunit catalysts $\left(\mathrm{d}_{\mathrm{n}}-\right.$ mean diameter, $\mathrm{SD}$ - standard deviation; $\mathrm{d}_{\mathrm{s}}$ - surface mean diameter)

a)

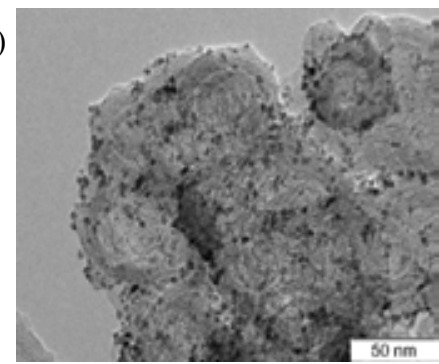

b)

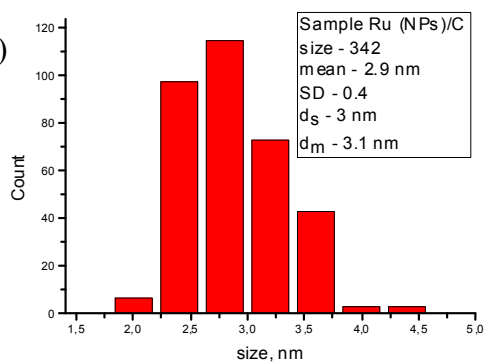

Fig. 2. TEM images (a) and histogram (b) of as-synthesized colloidal Ru NPs $\left(\mathrm{d}_{\mathrm{n}}\right.$ - mean diameter; SD - standard deviation; $d_{s}$ - surface mean diameter) 
a)

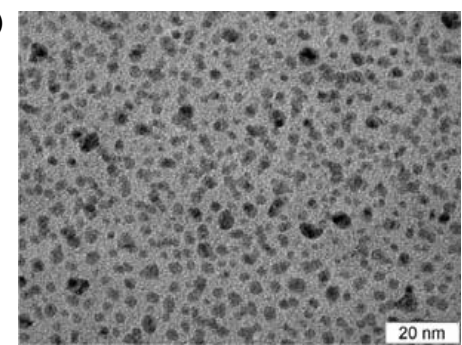

b)

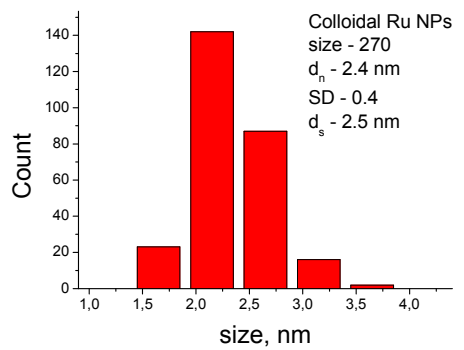

Fig. 3. TEM images (a) and histogram (b) of immobilized on Sibunit colloidal Ru NPs $\left(\mathrm{d}_{\mathrm{n}}-\right.$ mean diameter; SD standard deviation; $\mathrm{d}_{\mathrm{s}}$ - surface mean diameter)

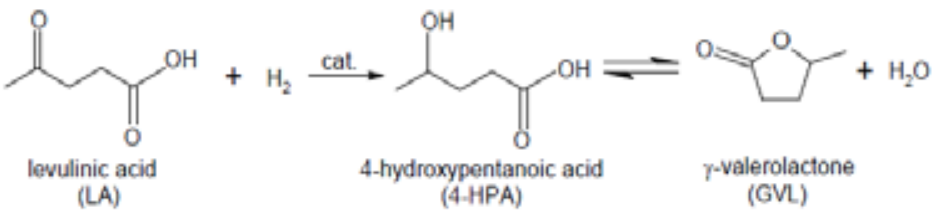

Fig. 4. Scheme of LA hydrogenation to GVL

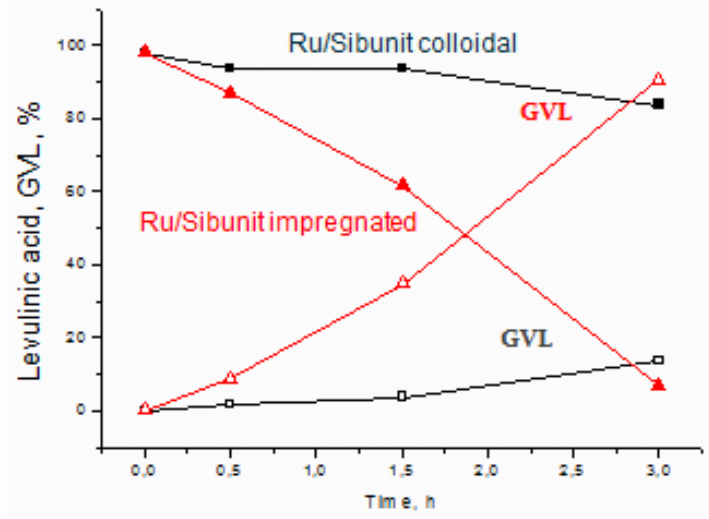

Fig. 5. LA hydrogenation over Ru/Sibunit (red triangle) and Ru(NPs)/Sibunit (black squares). Reaction conditions: levulinic acid $0.7 \mathrm{ml}, 1,4$-dioxane $15 \mathrm{ml}$, catalyst $0.24 \mathrm{~g}, \mathrm{~T}=165^{\circ} \mathrm{C}, 20$ bar $\mathrm{H}_{2}$

Catalytic runs showed that LA hydrogenation rate over a colloidal $\mathrm{Ru}(\mathrm{NPs}) / \mathrm{Sibunit}$ catalyst was much lower than over the impregnated Ru/Sibunit (Fig. 5). It could be explained by PVP hampering hydrogenation hindering the access of the substrate to the active sites.

Low activity of the colloidal catalyst can be increased by application of different methods of PVP removal procedure developed in our earlier research work [14]. Similarly to that study, two approaches were applied: in the first approach the colloidal solution of Ru metal particles was additionally washed by acetone followed by immobilization of purified colloidal NPs on Sibunit; while in the second approach Ru(NPs) immobilized on Sibunit were purified by various methods. All catalyst samples were studied by TEM and $\mathrm{N}_{2}$ physisorption before and after treatment, whereas some representative samples were also studied by XPS. The catalysts treated 
by the same methods in this work were denoted accordingly as those in our previous paper for convenience [14].

\subsection{PVP removal from Ru NPs colloids before immobilization}

The volume ratio between the amount of an initial Ru NPs colloid $(0.1 \mathrm{M})$ and acetone taken for washing of colloids was varied from 13 to 77 to alter a degree of PVP removal. The effect of the acetoneto-colloid ratio on the specific surface area (SSA), pore volume (PV), and average pore diameter $\left(\mathrm{D}_{\mathrm{av}}\right)$ as well as on the mean $\left(d_{n}\right)$ and average surface $\left(d_{s}\right)$ Ru NPs size is presented in Table 1.

An increase of acetone/colloid (volume/volume) ratio from 13 to 33 resulted in restoration of the surface area from 177 to $209 \mathrm{~m}^{2} / \mathrm{g}$ without noticeable changes in NPs size for $3 \mathrm{wt} \% \mathrm{Ru} / \mathrm{C}-1$ and $3 \mathrm{wt} . \% \mathrm{Ru} / \mathrm{C}-2$, respectively, with the same metal loading (Table 1). A comparison of values for $3 \mathrm{wt} . \%$

Table 1. Parameters of Ru(NPs)/Sibunit catalysts prepared from Ru NPs solution purified with acetone

\begin{tabular}{|c|c|c|c|c|c|c|}
\hline Catalyst & $\begin{array}{c}\text { Acetone/Colloid } \\
\text { (vol/vol) }\end{array}$ & $\mathrm{d}_{\mathrm{n}}, \mathrm{nm}$ & $\mathrm{d}_{\mathrm{s}}, \mathrm{nm}$ & $\mathrm{SSA}, \mathrm{m}^{2} / \mathrm{g}$ & $\mathrm{PV}, \mathrm{cm}^{3} / \mathrm{g}$ & $\mathrm{D}_{\mathrm{av}}, \mathrm{nm}$ \\
\hline 3 wt.\% Ru/C-1 & 13 & 2.5 & 2.7 & 177 & 0.40 & 9.0 \\
\hline 3 wt.\% Ru/C-2 & 33 & 2.7 & 2.9 & 209 & 0.42 & 8.0 \\
\hline 3 wt.\% Ru/C-3 & 33 & 2.7 & 2.8 & 209 & 0.41 & 6.9 \\
\hline 2 wt.\% Ru/C-4 & 13 & 2.2 & 2.3 & 233 & 0.49 & 8.4 \\
\hline 2 wt.\% Ru/C-5 & 77 & 2.5 & 2.6 & 350 & 0.57 & 6.6 \\
\hline
\end{tabular}

$\mathrm{Ru} / \mathrm{C}-2$ and 3 wt.\% Ru/C-3 confirms good reproducibility of the data. A similar trend of the surface area increase (from 233 to $350 \mathrm{~m}^{2} / \mathrm{g}$ ) with an increase in acetone-to-colloid ratio from 13 to 77 was observed for 2 wt.\% Ru/C-4 and 2 wt.\% Ru/C-5. Thus, additional colloidal Ru NPs washing with acetone prior to NPs immobilization on all investigated carbon supports resulted in PVP removal in terms of the textural properties, not affecting the particle size.

\subsection{PVP removal from $R u(N P S) / S i b u n i t$ colloidal catalysts after immobilization}

Different methods were applied to wipe out PVP from the Ru(NPs)/Sibunit catalyst such as washing the colloidal Ru NPs solution with acetone before immobilization on Sibunit or stripping PVP from immobilized Ru NPs with distilled water/acetic acid solution $\left(220^{\circ} \mathrm{C}, 25\right.$ bar $)$ as well as by thermal treatment in air $\left(180^{\circ} \mathrm{C}\right)$ or $\mathrm{H}_{2}\left(400^{\circ} \mathrm{C}\right)$, or $\mathrm{N}_{2}\left(500^{\circ} \mathrm{C}\right)$, or in air $\left(180^{\circ} \mathrm{C}\right)$ followed by $\mathrm{H}_{2}\left(400^{\circ} \mathrm{C}\right)$ [14]. The mean diameter of metal NPs additionally washed with acetone was ca. 1.8-2.4 nm allowing to attribute the catalytic behavior to a degree of capping agent removal rather than to the cluster size (Table 1). Solvothermal treatment of Sibunit immobilized Ru NPs regardless of the medium pH gave a rise in the surface area for Ru/C-4 from $233 \mathrm{~m}^{2} / \mathrm{g}$ to 287 and $273 \mathrm{~m}^{2} / \mathrm{g}$, correspondingly, as well as for $\mathrm{Ru} / \mathrm{C}-3$ from $209 \mathrm{~m}^{2} / \mathrm{g}$ to 295,321 and $291 \mathrm{~m}^{2} / \mathrm{g}$, correspondingly, when the catalysts were synthesized from the colloid with a lower ratio between acetone and colloid $(13 \div 33)$ (Table 2). The pretreatment of $\mathrm{Ru} / \mathrm{C}-5$ catalyst synthesized from a preliminary washed colloid (acetone-to-colloid ratio 77) did not noticeably affect textural properties. No Ru leaching was observed during Ru/Sibunit catalysts 
washing. Particles size distribution did not change dramatically, however a higher fraction of larger NPs in the medium with a higher content of acetic acid was observed with additionally washed Ru NPs $(\mathrm{Ru} / \mathrm{C}-5)$ being more stable under hydrothermal conditions than untreated one (Ru/C-3) (Table 2).

According to XPS data preliminary colloid washing in combination with the solvothermal treatment resulted in a the decrease in N1s intensity confirming complete PVP removal from the surface of 2 wt.\% Ru/C-5 catalyst (Fig. 6). At the same time partial Ru oxidation during the pretreatment in water was detected by XPS (Fig. 6).

Thereafter PVP-based Ru catalysts were subjected to annealing under different gas atmosphere and temperature regime conditions in order to decompose PVP (Table 3). High temperature heating of 3 wt.\% Ru/C-2 sample in nitrogen, argon and hydrogen resulted in the surface restoration on the one hand, and NPs sintering on the other hand. As can be seen from Table 3 the catalysts heated in $\mathrm{H}_{2}$ are characterized with a less prominent particle size growth. The mean NPs size for $2 \mathrm{wt} . \% \mathrm{Ru} / \mathrm{C}-5$ catalyst $(2.8 \mathrm{~nm})$ increased after thermal treatment in nitrogen up to $4.5 \mathrm{~nm}$, in argon up to $4.0 \mathrm{~nm}$ and in hydrogen up to $3.6 \mathrm{~nm}$ (Table 3).

Thus, the thermal treatment in hydrogen resulted in a smaller increase in Ru NPs size compared to reduction in inert atmosphere. Note, according to the interplanar spacing determined by TEM, some partial Ru oxidation was observed during the treatment of $2 \mathrm{wt} . \% \mathrm{Ru} / \mathrm{C}-5$ even in hydrogen. Probably it can be related to PVP decomposition on the oxygen containing fragments resulting in Ru oxidation.

Table 2. Results on solvothermal washing of Ru catalysts

\begin{tabular}{|c|c|c|c|c|c|c|c|}
\hline Catalyst & $\begin{array}{l}\text { PVP removal } \\
\text { procedure }\end{array}$ & $\begin{array}{l}\text { Acetone/ } \\
\text { colloid }\end{array}$ & $\mathrm{d}_{\mathrm{n}}, \mathrm{nm}$ & $\mathrm{d}_{\mathrm{s}}, \mathrm{nm}$ & $\mathrm{SSA}, \mathrm{m}^{2} / \mathrm{g}$ & $\mathrm{PV}, \mathrm{cm}^{3} / \mathrm{g}$ & $\mathrm{D}_{\mathrm{av}}, \mathrm{nm}$ \\
\hline 3 wt.\% Ru/C-3 & \multirow{3}{*}{$\mathrm{H}_{2} \mathrm{O}, 4 \mathrm{~h}$} & 33 & 3.3 & 3.5 & 295 & 0.48 & 6.6 \\
\hline 2 wt.\% Ru/C-4 & & 13 & 3.0 & 3.1 & 287 & 0.50 & 6.8 \\
\hline 2 wt.\% Ru/C-5 & & 77 & 3.1 & 3.4 & 346 & 0.56 & 6.5 \\
\hline 3 wt. $\% \mathrm{Ru} / \mathrm{C}-3^{\mathrm{a}}$ & \multirow{2}{*}{$\mathrm{CH}_{3} \mathrm{COOH}, 4 \mathrm{~h}$} & 33 & 3.7 & 3.9 & 321 & 0.53 & 7.0 \\
\hline 3 wt.\% Ru/C-3 ${ }^{b}$ & & 33 & 3.6 & 3.8 & 291 & 0.51 & 7.0 \\
\hline
\end{tabular}

${ }^{a}$ Aqueous solution of acetic acid $0.02 \mathrm{M}$.

${ }^{\mathrm{b}}$ Aqueous solution of acetic acid $0.08 \mathrm{M}$.

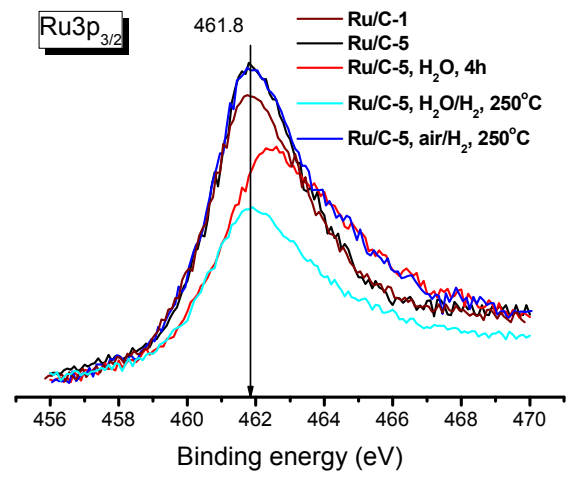

a)

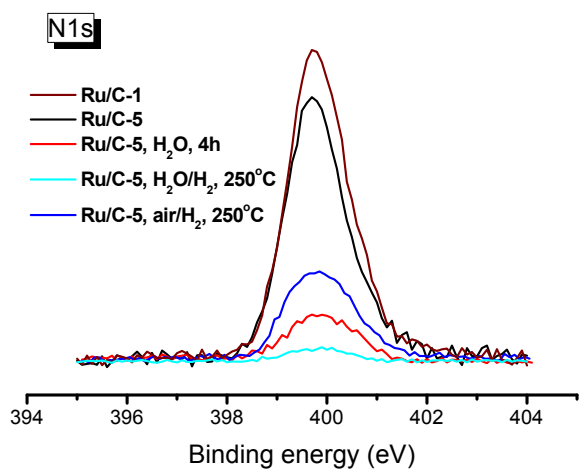

b)

Fig. 6. XP spectra of Ru3p $p_{3 / 2}$ (a) and N1s regions (b) of $\mathrm{Ru} / \mathrm{C}-1$ and $\mathrm{Ru} / \mathrm{C}-5$ series 
Table 3. Results on thermal PVP degradation over Ru catalysts

\begin{tabular}{|c|c|c|c|c|c|c|c|}
\hline Catalyst & $\begin{array}{l}\text { PVP removal } \\
\text { procedure }\end{array}$ & $\begin{array}{l}\text { Acetone/ } \\
\text { colloid }\end{array}$ & $\mathrm{d}_{\mathrm{n}}, \mathrm{nm}$ & $\mathrm{d}_{\mathrm{s}}, \mathrm{nm}$ & $\mathrm{SSA}, \mathrm{m}^{2} / \mathrm{g}$ & $\mathrm{PV}, \mathrm{cm}^{3} / \mathrm{g}$ & $\mathrm{D}_{\mathrm{av}}, \mathrm{nm}$ \\
\hline $\begin{array}{l}3 \text { wt.\% Ru/C-2 } \\
2 \text { wt.\% Ru/C-5 }\end{array}$ & $\mathrm{H}_{2}, 400^{\circ} \mathrm{C}$ & $\begin{array}{l}33 \\
77\end{array}$ & $\begin{array}{l}3.6 \\
\text { ox }\end{array}$ & $\begin{array}{l}4.4 \\
\text { ox }\end{array}$ & $\begin{array}{l}336 \\
378\end{array}$ & $\begin{array}{l}0.54 \\
0.70\end{array}$ & $\begin{array}{l}6.4 \\
7.4\end{array}$ \\
\hline $\begin{array}{l}3 \text { wt. } \% \mathrm{Ru} / \mathrm{C}-2 \\
3 \text { wt.\% Ru/C-2 }\end{array}$ & $\begin{array}{l}\mathrm{N}_{2}, 500^{\circ} \mathrm{C} \\
\mathrm{Ar}, 500^{\circ} \mathrm{C}\end{array}$ & $\begin{array}{l}33 \\
33\end{array}$ & $\begin{array}{l}4.5 \\
4.0\end{array}$ & $\begin{array}{l}5.3 \\
5.5\end{array}$ & $\begin{array}{c}296 \\
-\end{array}$ & $\begin{array}{c}0.54 \\
-\end{array}$ & $\begin{array}{c}7.3 \\
-\end{array}$ \\
\hline $\begin{array}{l}3 \text { wt. } \% \mathrm{Ru} / \mathrm{C}-3 \\
2 \text { wt.\% Ru/C-5 }\end{array}$ & air, $180^{\circ} \mathrm{C}$ & $\begin{array}{l}33 \\
77\end{array}$ & $\begin{array}{l}2.9 \\
2.6\end{array}$ & $\begin{array}{l}3.1 \\
2.7\end{array}$ & $\begin{array}{l}256 \\
305\end{array}$ & $\begin{array}{l}0.43 \\
0.53\end{array}$ & $\begin{array}{l}6.7 \\
7.0\end{array}$ \\
\hline 2 wt. $\% \mathrm{Ru} / \mathrm{C}-5$ & $\begin{array}{l}\text { air, } 180^{\circ} \mathrm{C} ; \\
\mathrm{H}_{2}, 400^{\circ} \mathrm{C}\end{array}$ & 77 & 3.4 & 3.7 & 351 & 0.54 & 6.1 \\
\hline $\begin{array}{l}2 \text { wt. } \% \mathrm{Ru} / \mathrm{C}-4 \\
2 \text { wt.\% } \% \text { Ru/C-5 }\end{array}$ & $\begin{array}{l}\text { air, } 180^{\circ} \mathrm{C} ; \\
\mathrm{H}_{2}, 250^{\circ} \mathrm{C}\end{array}$ & $\begin{array}{l}13 \\
77\end{array}$ & $\begin{array}{l}2.5 \\
2.8\end{array}$ & $\begin{array}{l}2.6 \\
3.0\end{array}$ & $\begin{array}{l}244 \\
310\end{array}$ & $\begin{array}{l}0.45 \\
0.50\end{array}$ & $\begin{array}{l}7.4 \\
6.5\end{array}$ \\
\hline
\end{tabular}

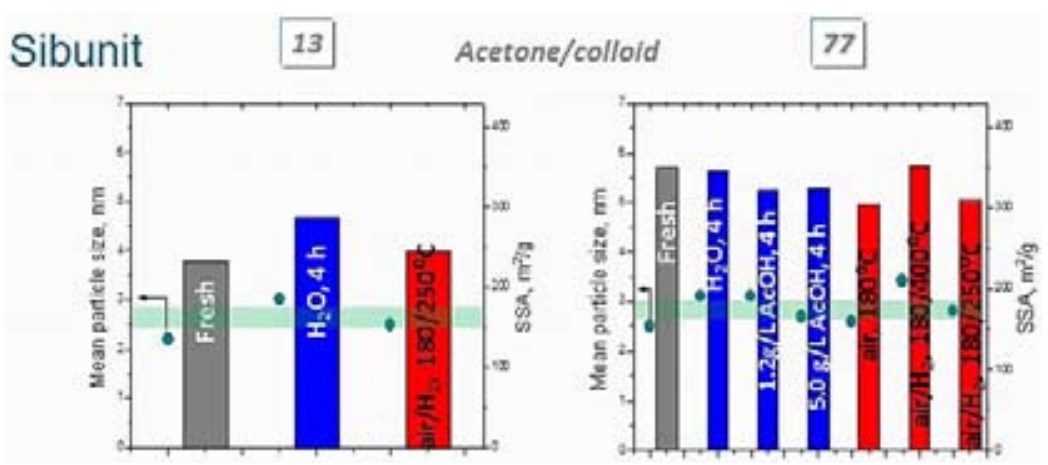

Fig. 7. Effect of PVP removal from Ru(NPs)/Sibunit on the mean Ru NPs size (left Y axis) and catalyst specific surface area (right $\mathrm{Y}$ axis)

Sibunit immobilized Ru NPs were also treated in air at $180^{\circ} \mathrm{C}$ for $0.5 \mathrm{~h}$ which resulted in an increase in the surface area from 209 to $256 \mathrm{~m}^{2} / \mathrm{g}$ without a significant change in NPs size (Table 3). According to XPS data in the case of thermal treatment in air Ru was found to be mainly in the metallic state with the presence of a small fraction of Ru cations resulting in a shift of the corresponding peak for metallic Ru at $461 \mathrm{eV}$ (Fig. 6).

The results of the Ru(NPs) different purification methods are summarized on Fig. 7. Analysis of results allows to determine the method provided stabilization of Ru NPs size and Ru metallic state as well as high specific surface area restoration, namely treatment with air at $180^{\circ} \mathrm{C}$ followed by reduction with hydrogen at $400^{\circ} \mathrm{C}$ (Fig. 7).

\subsection{Effect of PVP removal procedure on catalytic properties of Ru(NPs)/Sibunit}

$\mathrm{Ru}(\mathrm{NPs}) /$ Sibunit catalyst after thermal treatment with air at $180^{\circ} \mathrm{C}$ followed by exposure to hydrogen at $400^{\circ} \mathrm{C}$ was used for LA hydrogenation into GVL. It was found that the colloidal catalyst with initially low activity in LA hydrogenation (Fig. 8) significantly improved activity approaching that of the impregnated Ru/Sibunit catalyst (Fig. 8). 


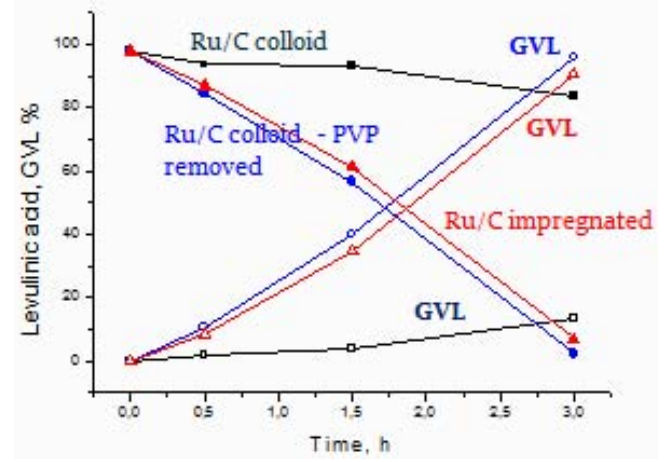

Fig. 8. LA hydrogenation over Ru/Sibunit (red triangle), Ru(NPs)/Sibunit (black squares) and Ru(NPs)/Sibunit after thermal treatment with air at $180^{\circ} \mathrm{C}$ followed by exposure to hydrogen at $400^{\circ} \mathrm{C}$ (blue circles). Reaction conditions levulinic acid $0.7 \mathrm{ml}, 1,4$-dioxane $15 \mathrm{ml}$, catalyst $240 \mathrm{mg}, \mathrm{T}=165^{\circ} \mathrm{C}, 20 \mathrm{bar} \mathrm{H}_{2}$

\section{Conclusions}

Levulinic acid hydrogenation into $\gamma$-valerolactone was studied over Ru supported on mesoporous carbon Sibunit catalysts. They were prepared by two different ways: (i) immobilization of colloidal metallic Ru NPs, (ii) impregnation of the carbon support with $\mathrm{RuCl}_{3}$ followed by reduction with molecular hydrogen into metallic NPs. Impregnated Ru catalysts showed initially levulinic acid conversion much higher than exhibited by the catalysts prepared by immobilization of colloidal metallic Ru NPs. A specific protocol for preparation of the carbon supported colloidal Ru NPs was supplemented by PVP removal procedure and applied for design of more effective catalysts. The optimal PVP removal procedure was found to be thermal treatment with air at $180^{\circ} \mathrm{C}$ followed by exposure to hydrogen at $400^{\circ} \mathrm{C}$. This method of PVP decomposition enabled high resistance to metal NPs leaching in acidic media keeping the Ru initial size. Activity in LA hydrogenation of colloidal $\mathrm{Ru} / \mathrm{C}$ after PVP removal by this method was shown to be comparable with traditional impregnated catalysts having a benefit of fine tuning the size of Ru catalysts over different supports including zeolites.

\section{Acknowledgements}

The authors are grateful to Dr. E. Gerasimov (TEM), Dr. I. Prosvirin (XPS), I. Krayevskaya (XRF) and $\mathrm{T}$. Yefimenko ( $\mathrm{N}_{2}$ physisorption) for catalysts characterization.

This work was supported by RFBR Grant 18-53-45013 IND_a and INT/RUS/RFBR/P-323 project. Part of work (XRF and N2 physisorption) was supported by Ministry of Science and Higher Education of the Russian Federation (project AAAA-A17-117041710075-0).

\section{References}

1. Quinson J., Neumann S., Wannmacher T., Kacenauskaite L., Inaba M., Bucher J., Bizzotto F., Simonsen S.B., Theil Kuhn L., Bujak D., Zana A., Arenz M., Kunz S. Colloids for catalysts: a concept for the preparation of superior catalysts of industrial relevance. Angewandte Chemie International Edition 2018. Vol. 130, P. $12518-12521$.

2. Deutschmann O., Knçzinger H., Kochloefl K., Turek T. Ullmann's Encyclopedia of Industrial Chemistry, Wiley, New York, 2009. 
3. Jia C.-J., Schuth F. Colloidal metal nanoparticles as a component of designed catalyst. Physical Chemistry Chemical Physics 2011, Vol. 13, P. 2457-2487.

4. Kuwahara Y., Magatani Y., Yamashit H. Ru nanoparticles confined in Zr-containing spherical mesoporous silica containers for hydrogenation of levulinic acid and its esters into $\gamma$-valerolactone at ambient conditions. Catalysis Today 2015. Vol. 258, P. 262-269.

5. Protsenko I.I., Abusuek D.A., Nikoshvili L.Zh., Bykova, A.V., Matveeva V.G., Sulman E.M. The use of the Ru-containing catalyst based on hypercrosslinked polystyrene in the hydrogenation of levulinic acid to $\gamma$-valerolactone. Catalysis in Industry 2018. Vol. 10, P. 301-312.

6. Serrano-Ruiz J.C., Wang D., Dumesic J.A. Catalytic upgrading of levulinic acid to 5-nonanone. Green Chemistry 2010. Vol. 12, P. 574-577.

7. Yan Z.-P., Lin L., Liu S. Synthesis of $\gamma$-valerolactone by hydrogenation of biomass-derived levulinic acid over Ru/C catalyst. Energy Fuels 2009. Vol. 23, P. 3853-3858.

8. Al-Shaal M.G., Wright W.R.H., Palkovits R. Exploring the ruthenium catalysed synthesis of $\gamma$-valerolactone in alcohols and utilisation of mild solvent-free reaction conditions. Green Chemistry 2012. Vol. 14, P. 1260-1263.

9. Manzer L.E. Catalytic synthesis of $\alpha$-methylene- $\gamma$-valerolactone: a biomass-derived acrylic monomer. Applied Catalysis A: General 2004. Vol. 272, P. 249-256.

10. Bourne R.A., Stevens J.G., Ke J., Poliakoff M. Maximising opportunities in supercritical chemistry: the continuous conversion of levulinic acid to $\gamma$-valerolactone in $\mathrm{CO}_{2}$. Chemical Communications 2007. P. 4632- 4634.

11. Li C., Ni X., Di X., Liang C. Aqueous phase hydrogenation of levulinic acid to $\gamma$-valerolactone on supported $\mathrm{Ru}$ catalysts prepared by microwave-assisted thermolytic method. Ranliao Huaxue Xuebao 2018. Vol. 46(2), P. 161-170.

12. Simakova I.L., Murzin D.Yu. Ruthenium nanomaterials: an overview of recent developments in colloidal synthesis, properties, and potential applications. in Advanced Nanomaterials for Catalysis and Energy Synthesis, Characterization and Applications (Ed. V.A. Sadykov), Elsevier, 2018, P. 99-141.

13. Simakova I.L., Demidova Yu.S., Prosvirin I.P., Murzin D.Yu., Simakov A.V. Development of polyol method for the synthesis of concentrated colloids of PVP-stabilised Ru nanoparticles. International Journal of Nanotechnology 2016. Vol. 13, P. 15-27.

14. Simakova I.L., Demidova Yu.S., Gläsel J., Murzina E.V. Controlled synthesis of PVP-based carbon supported Ru nanoparticles: synthesis approaches, characterization, capping agent removal and catalytic behavior. Catalysis Science and Technology 2016. Vol. 6, P. 8490-8504.

15. Simakova I.L., Demidova Y.S., Murzina E.V., Aho A., Murzin D.Yu. Structure sensitivity in catalytic hydrogenation of galactose and arabinose over $\mathrm{Ru} / \mathrm{C}$ catalysts. Catalysis Letters 2016. Vol. 146, P. 1291-1299.

16. Demidova Yu.S., Simakova I.L., Schubert T., Murzin D.Yu. The synthesis of Ru/CNF colloidal catalysts: Comparison of ex-situ and in-situ methods. Materials Today: Proceedings 2017. Vol. 4, P. 11364-11370.

17. Zaytseva Yu.A., Panchenko V.N., Simonov M.N., Shutilov A.A., Zenkovets G.N., Simakova I.L., Parmon V.N. Effect of gas atmosphere on catalytic behaviour of zirconia, ceria and ceria-zirconia catalysts in valeric acid ketonization. Topics in Catalysis 2013. Vol. 56, P. 846-855. 